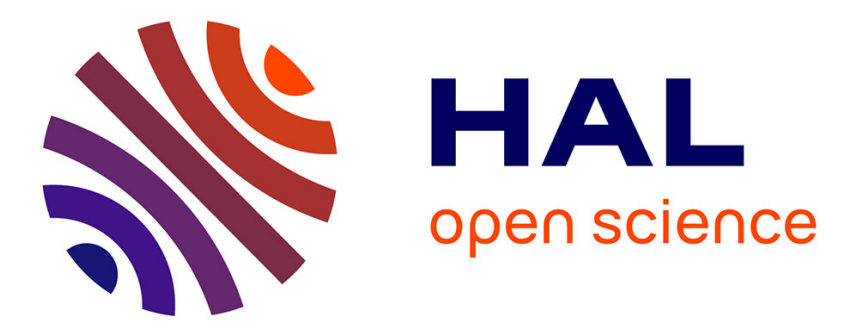

\title{
A presumptive role for GABA in the stimulatory effects of desgly10 (D-A1A6) LHRH ethylamide and pimozide on the gonadotropin release in carp
}

I. Roelants, P. Epler, T. Mikolajczyk, Bernard Breton, K. Bieniarz, F. Ollevier

\section{- To cite this version:}

I. Roelants, P. Epler, T. Mikolajczyk, Bernard Breton, K. Bieniarz, et al.. A presumptive role for GABA in the stimulatory effects of desgly10 (D-A1A6) LHRH ethylamide and pimozide on the gonadotropin release in carp. Life Sciences, 1990, 47, pp.1801-1812. 10.1016/0024-3205(90)90282-V . hal-02716135

\section{HAL Id: hal-02716135 \\ https://hal.inrae.fr/hal-02716135}

Submitted on 1 Jun 2020

HAL is a multi-disciplinary open access archive for the deposit and dissemination of scientific research documents, whether they are published or not. The documents may come from teaching and research institutions in France or abroad, or from public or private research centers.
L'archive ouverte pluridisciplinaire $\mathbf{H A L}$, est destinée au dépôt et à la diffusion de documents scientifiques de niveau recherche, publiés ou non, émanant des établissements d'enseignement et de recherche français ou étrangers, des laboratoires publics ou privés. 
A PRESUMPTIVE ROLE FOR GABA IN THE STIMULATORY EFFECTS OF DESGLY $\left.{ }^{10},[D-A] A^{6}\right]-L H R H-E T H Y L A M I D E$ AND PIMOZIDE ON THE GONADOTROPIN RELEASE IN CARP

I. Roelants 1/3) P. Epler 1) T. Mikolajczyk 1) B. Breton 2) K. Bieniarz 1) F. Ollevier 3).

Dept. of Ichthyobiology and Fisheries, Agricultural Academy, Cracow - Mydlniki, Poland 1); Laboratoire de Physiologie des Poissons I.N.R.A., Campus de Beaulieu, Rennes, France 2) and Zoological Institute, Catholic University of Louvain, Louvain, Belgium 3).

(Received in final form September 7, 1990)

\section{Summary}

To investigate the effect of endogenous $\gamma$ aminobutyric acid (GABA) on the blood maturating gonadotropin ( $\mathrm{GtH}$ ) levels, or to study its interaction with pimozide (dopamine antagonist) and a luteinizing hormone- releasing hormone analog (LHRH-a), sexually mature male and female carps were treated with drugs that may either inhibit GABA biosynthesis or GABA degradation. In females the irreversible inhibitor of GABA- transaminase, $p$-vinyl GABA (GVG), which was to increase the endogenous GABA-ergic tone, had no influence on GtH release. On the other hand, the increased GtH response to the combination of pimozide (PIM) and LHRH-a was clearly enhanced by the administration of 3-mercaptopropionic acid (MPA), an inhibitor of the rate limiting enzyme of GABAbiosynthesis. In males the GABA-ergic compound, valproic acid (DPA) decreased LHRH-a stimulated GtH levels. In male carps that received PIM to diminish the dopaminergic inhibition of $\mathrm{GtH}$ release, the spermiating response to LHRH-a was increased by administration of MPA. These data suggest that GABA interacts with the action of dopamine and the gonadotropin releasing hormone (GnRH) on the release of GtH.

It has been well established, in vivo and in vitro, that

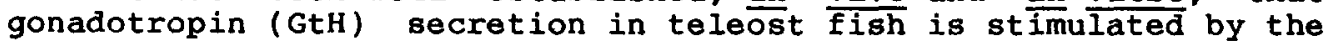
gonadotropin hormone releasing hormone (GnRH) and inhibited by dopamine (DA) $(1,2)$. A direct action by either neurotransmitter upon the pituitary receptors regulates the $G t H$ release $(3-5)$. Administration of a D2- type dopamine receptor blocker potentiates the ability of GnRH, and its superactive analogues (GnRH-a) to induce $G t H$ release in cyprinids (6-10), salmonids (11), African catfish, Clarias lazera (12) and in loach, Paragmisgurus dabryanus $(13-14)$.

Other neurotransmitters that have been shown to participate in the neuroendocrine regulation of $\mathrm{GtH}$ release in teleosts are 
norepinephrine (NE) (15-17), opioid peptides (18), serotonin (5HT) (19) and, recently, also neuropeptide-Y (NPY) (20,21). Whether $\gamma$-aminobutyric acid (GABA) alters GtH-release in teleosts is not known. This GABA-ergic action would be logical since in mammals GABA has been shown to interact with several central neurotransmitters that affect the secretion of pituitary gonadotropin, as LHRH $(22,23), \mathrm{NE}(24), \mathrm{DA}(25,26), 5-\mathrm{HT}(27)$ and opioid peptides ( 28 ).

On the other hand in teleost fish, immunocytochemical evidence suggests a direct innervation of the anterior pituitary and the presence of GABA-ergic neuron endings near the gonadotrope cells (29). While Follenius (30) showed that tritium labeled GABA after intraperitoneal injection particularly fixed itself in the neurohypophysis of the teleost, Gasterosteus aculeatus.

These facts have given impetus to investigate the GABA-ergic modulation of spontaneous $G$ tH secretion and to investigate the influence of GABA on luteinizing hormone releasing hormone analogue (LHRH-a) or LHRH-a + pimozide stimulated GtH release in sexual mature male and female carp, Cyprinus carpio $L$.

\section{Methods}

This study was performed in two successive experiments carried out at the Department of Ichthyobiology and Fisheries (DIF) of the Agricultural Academy in Cracow.

Animals. Mid-April 1988, ninety-six male carps (scaled, approximately five years of age, body weight (b.w.) $=3.2 \pm 1.3$ $\mathrm{kg}$, mean \pm SD) were transported from the Governmental zator Fisheries Farm to the DIF. After weighing and tagging by finclipping, the fish were placed in twelve 950 liter flow-through basins, eight fish per basin. Prior to the experiment, they were adapted for four days to $17^{\circ} \mathrm{C}$ and a simulated natural photoperiod appropriate for the time of year (14L : 10D).

Mid-June 1988, eighty-four unscaled sexually mature female carps (approximately 6 years of age, b.w. $=2.1 \pm 0.5 \mathrm{~kg}$, mean \pm SD) raised at the DIF were selected from a mixed pond-stock and brought into the laboratory to be anesthetized by immersion in a propanidide solution. After weighing, the fish were branded with a number code on their skin by an electrically heated nearcircular loop wire. In groups of seven they were then placed in a 950 liter rectangular flow-through basins and exposed for two days to $18{ }^{\circ} \mathrm{C}$ and a simulated natural photoperiod appropriate for the time of year $(16 \mathrm{~L}: 8 \mathrm{D})$.

Drugs. Pimozide (Pim), valproic acid (DPA) and $v$-vinyl GABA (GVG) were generous gifts from respectively Janssen pharmaceuticals LtD., Beerse, Belgium; Labaz-sanofi, Brussels, Belgium and Merell Dow Pharmaceuticals INC., Ohio, USA. Des Gly ${ }^{10},\left[\mathrm{D}-\mathrm{Al} \mathrm{a}^{6}\right]-\mathrm{LHRH}-$ ethylamide (LHRH-a) and 3-mercaptopropionic acid (MPA) were purchased from Sigma, St. Louis, MO, USA.

MPA is a potent inhibitor of the GABA biosynthesis (31). The GABA-mimetic drug, DPA, has been shown to increase brain GABA levels (32). GVG, an irreversible inhibitor of the main GABA degradating enzyme, GABA transaminase (GABA-T), increased the brain levels of GABA in gerbils (33). 
General experimental procedure. Before injection all drugs were freshly made in saline $(0.68 \mathrm{NaCl})$, with pimozide as a suspension and the other compounds as solutions. They were then injected intraperitoneally with each carp receiving the same volume of saline per kilogram body weight.

The fish were anesthetized by immersion in a propanidide solution. Blood was sampled by caudal punction with a 23 gauge needle attached to a heparinized syringe. Blood samples were immediately centrifuged and the supernatant plasma was placed into microcentrifuge test tubes by syringes rinsed with a heparine (3500 j.m.) - merthiolate $(10 \mathrm{mg} / \mathrm{ml})$ solution. The plasma samples were then stored at $-20^{\circ} \mathrm{C}$ until they were shipped, on dry ice, to the Laboratory of Ichthyophysiology, INRA, Rennes, France, where they were assayed for GtH using a specific RIA developed by Breton et al (34).

Effects of MPA and DPA injections on the PIM + LHRH-A stimulated GtH release and spermiation in carp.

TABLE $\underline{1}$.

Treatment closure of the various groups of the first experiment performed mid- April on male carps $\left(17^{\circ} \mathrm{C}, 14 \mathrm{~L}: 10 \mathrm{D}\right)$.

\begin{tabular}{lcccc} 
Group & $\begin{array}{l}\text { Number of } \\
\text { fish }\end{array}$ & $\begin{array}{c}\text { Body weight* } \\
(\mathbf{k g})\end{array}$ & $\begin{array}{l}\text { First } \\
\text { injections } \\
(0 \text { hour })\end{array}$ & $\begin{array}{l}\text { Last } \\
\text { injection } \\
(2 \text { hour })\end{array}$ \\
\hline$I-1$ & 8 & $2.9 \pm 1.2$ & SAL + SAL & SAL \\
$I-2$ & 8 & $3.4 \pm 1.4$ & SAL + MPA & SAL \\
$I-3$ & 8 & $3.2 \pm 1.2$ & SAL + DPA & SAL \\
$I-4$ & 8 & $3.0 \pm 1.2$ & SAL + SAL & LHRH-a \\
$I-5$ & 8 & $3.3 \pm 1.2$ & SAL + MPA & LHRH-a \\
$I-6$ & 8 & $3.1 \pm 1.2$ & SAL + DPA & LHRH-a \\
$I-7$ & 8 & $3.1 \pm 1.3$ & PIM + SAL & SAL \\
$I-8$ & 8 & $3.6 \pm 1.4$ & PIM + MPA & SAL \\
$I-9$ & 8 & $3.1 \pm 1.4$ & PIM + DPA & SAL \\
I-10 & 8 & $3.0 \pm 1.5$ & PIM + SAL & LHRH-a \\
I-11 & 8 & $3.3 \pm 1.4$ & PIM + MPA & LHRH-a \\
I-12 & 8 & $3.4 \pm 1.6$ & PIM + DPA & LHRH-a \\
\hline
\end{tabular}

* Values are means \pm SD

Blood sampling $0,2,6,10$ hours after the initial injection.

The saline vehicle, DPA $(30 \mathrm{mg} / \mathrm{kg} \mathrm{b.w.}), \operatorname{MPA}(2.5 \mathrm{mg} / \mathrm{kg} \mathrm{b.w.})$ and pimozide $(10 \mathrm{mg} / \mathrm{kg}$ b.w.) were administered in a first injection at $9 \mathrm{a} . \mathrm{m}$. LHRH-a $(50 \mu \mathrm{g} / \mathrm{kg} \mathrm{b.w.)}$ or its vehicle was injected two hours later. The milt volume was collected in a test tube by squeezing the abdomen. This stripping was performed blind, with the experimenter unaware of the treatment group to which the fish would be assigned. Blood was drawn several times, as indicated in table 1 .

Effects of MPA and GVG on PIM + LHRH-A stimulated GtH release and ovulation in female carp. The saline vehicle, MPA (5 mg/kg b.w.), GVG (100 mg/kg b.w.) and pimozide ( $5 \mathrm{mg} / \mathrm{kg} \mathrm{b.w.)} \mathrm{were} \mathrm{administered}$ in a first injection, at 9 a.m. LHRH-A ( $50 \mu \mathrm{g} / \mathrm{kg} \mathrm{b.w.)} \mathrm{or} \mathrm{its}$ 
vehicle was injected 2 hours after the initial injection. Blood was drawn serially as indicated in table 2. Ovulation was checked during blood sampling and at the $32 \mathrm{~h}$ and $48 \mathrm{~h}$, after the last injection.

\section{TABLE $\underline{2}$.}

Treatment closure of the various groups of the second experiment performed mid- June on female carps $\left(18^{\circ} \mathrm{C}, 16 \mathrm{~L}: 8 \mathrm{D}\right)$.

\begin{tabular}{|c|c|c|c|c|}
\hline Group & $\begin{array}{l}\text { Number of } \\
\text { fish }\end{array}$ & $\begin{array}{c}\text { Body weight * } \\
(\mathrm{kg})\end{array}$ & $\begin{array}{l}\text { First } \\
\text { injections } \\
(0 \text { hour })\end{array}$ & $\begin{array}{l}\text { Last } \\
\text { injection } \\
\text { ( } 2 \text { hour })\end{array}$ \\
\hline $\begin{array}{l}I I-1 \\
I I I-2 \\
I I I-3 \\
I I I-4 \\
I I I-5 \\
I I I-6 \\
I I-7 \\
I I I-8 \\
I I I-9 \\
I I I-10 \\
I I I-11 \\
I I I-12\end{array}$ & $\begin{array}{l}7 \\
7 \\
7 \\
7 \\
7 \\
7 \\
7 \\
7 \\
7 \\
7 \\
7 \\
7\end{array}$ & $\begin{array}{l}2.5 \pm 0.5 \\
2.1 \pm 0.6 \\
1.9 \pm 0.3 \\
2.2 \pm 0.3 \\
2.0 \pm 0.5 \\
2.1 \pm 0.5 \\
2.0 \pm 0.6 \\
2.1 \pm 0.1 \\
2.3 \pm 0.6 \\
1.9 \pm 0.5 \\
1.9 \pm 0.9 \\
2.0 \pm 0.4\end{array}$ & $\begin{array}{l}\text { SAL + SAL } \\
\text { SAL + MPA } \\
\text { SAL + GVG } \\
\text { SAL + SAL } \\
\text { SAL + MPA } \\
\text { SAL + GVG } \\
P I M+S A L \\
P I M+M P A \\
P I M+G V G \\
P I M+S A L \\
P I M+M P A \\
P I M+G V G\end{array}$ & $\begin{array}{l}\text { SAL } \\
\text { SAL } \\
\text { SAL } \\
\text { LHRH-a } \\
\text { LHRH-a } \\
\text { LHRH-a } \\
\text { SAL } \\
\text { SAL } \\
\text { SAL } \\
\text { LHRH-a } \\
\text { LHRH-a } \\
\text { LHRH-a }\end{array}$ \\
\hline
\end{tabular}

Statistics. The Duncan test was performed to compare pretreatment (zero hour) and posttreatment plasma GtH levels within the experimental groups. The Mann-Whitney U test was used to control statistically the similarity of the pretreatment $G \mathrm{tH}$ values and to test significant differences in the milt production between groups. By-Two Way Variance Analysis the changes in GtH release, as a response to fish's assigned treatment, was tested for statistical differences. The ovulation rates between groups were compared by Fisher's exact test.

\section{Results}

Experiment 1

Effect of MPA and DPA on the PIM + LHRH-a stimulated GtH release and spermiation in carp.

a- Gonadotropin concentrations (Fig. 1). All results are reported as means $\pm \mathrm{SE}$. In the saline treated group, the posttreatment $G t H$ values did not differ statistically from the zero hour control values. Since the zero hour control values were significantly different between the groups, statistical comparison was done on the plasma GtH values expressed as a percentage of the zero hour control. 

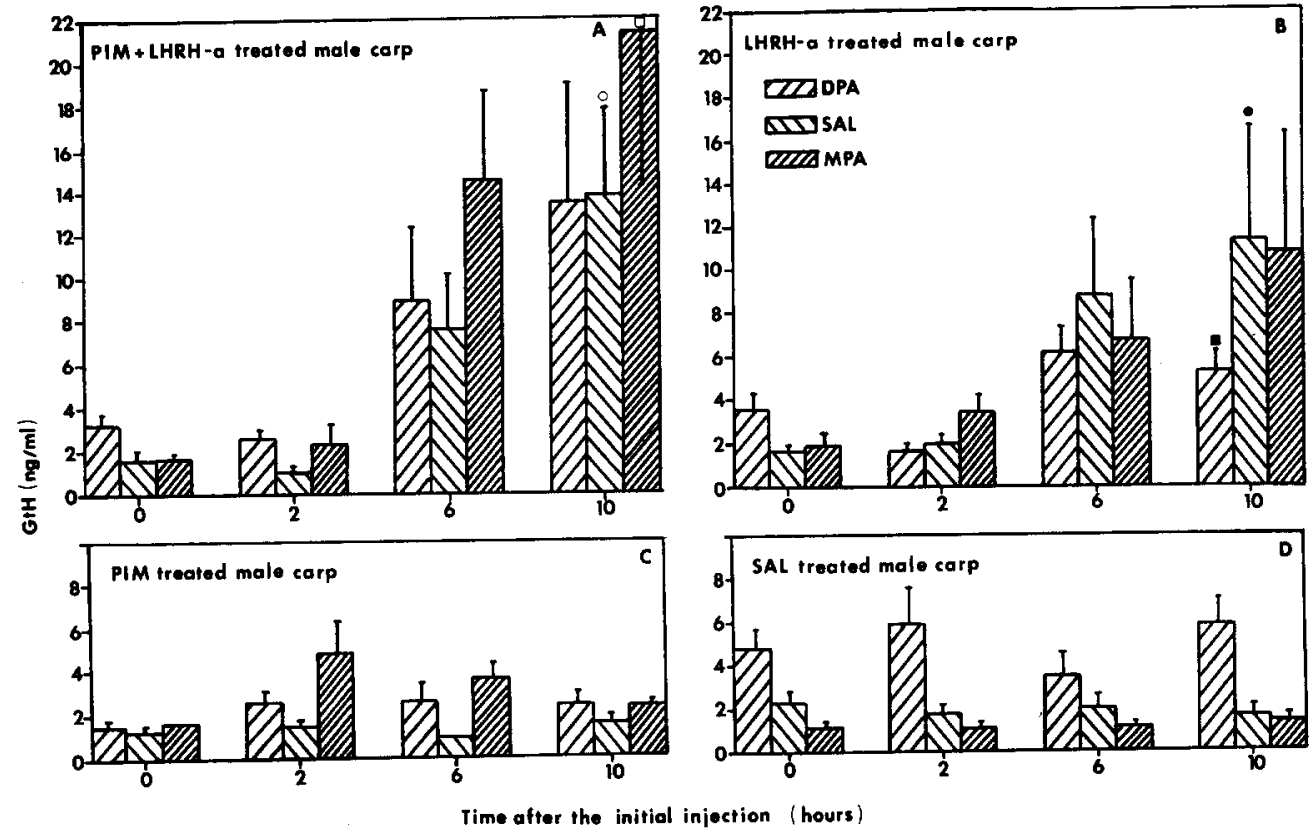

FIG. 1

Effect the GABA-mimetic compound, DPA and of the inhibitor of GABA biosynthesis, MPA, alone or in combination with LHRH-a, PIM or LHRH-a + PIM on the plasma GtH levels in male carp (mean $\pm S E, N=$ 8). $0 \mathrm{~h}$ and $2 \mathrm{~h}$ are the moment of the initial injection and of the second injection respectively (treatment closure under 'Materials and Methods). SE not shown are too small for scale. Statistical differences in the postreatment GtH release :

ovs to vehicle control (in panel D).

-vs to vehicle control (in panel D).

avs to LHRH-a + DPA (in panel B).

vvs to LHRH-a + SAL (in panel B).

The GtH values in pretreatment control and posttreatment control fish (D) were not significantly different, whereas the introduction of LHRH-a (B) or LHRH-a in combination with pimozide (A) significantly increased the plasma GtH concentrations (P $<0.005$ and $P<0.025$, respectively). The GtH release response to both this treatments, however, did not differ significantly (P $<0.1)$.

In the vehicle injected control groups (D), the plasma GtH levels were unaffected by MPA or by DPA. However, in carps that were injected with a combination of PIM, LHRH-a and MPA (A) the GtH release increased significantly more than in those that received PIM, LHRH-a and DPA (A) ( $\mathrm{P}<0.05)$, whereas the increased GtH release response to LHRH-a (B) was lower in carps that were injected additionally with DPA $(\mathrm{P}<0.05)$.

b- Spermiating response (Fig 2). Changes in the milt volume per body weight (means SE) expelled by hand massage were measured. 


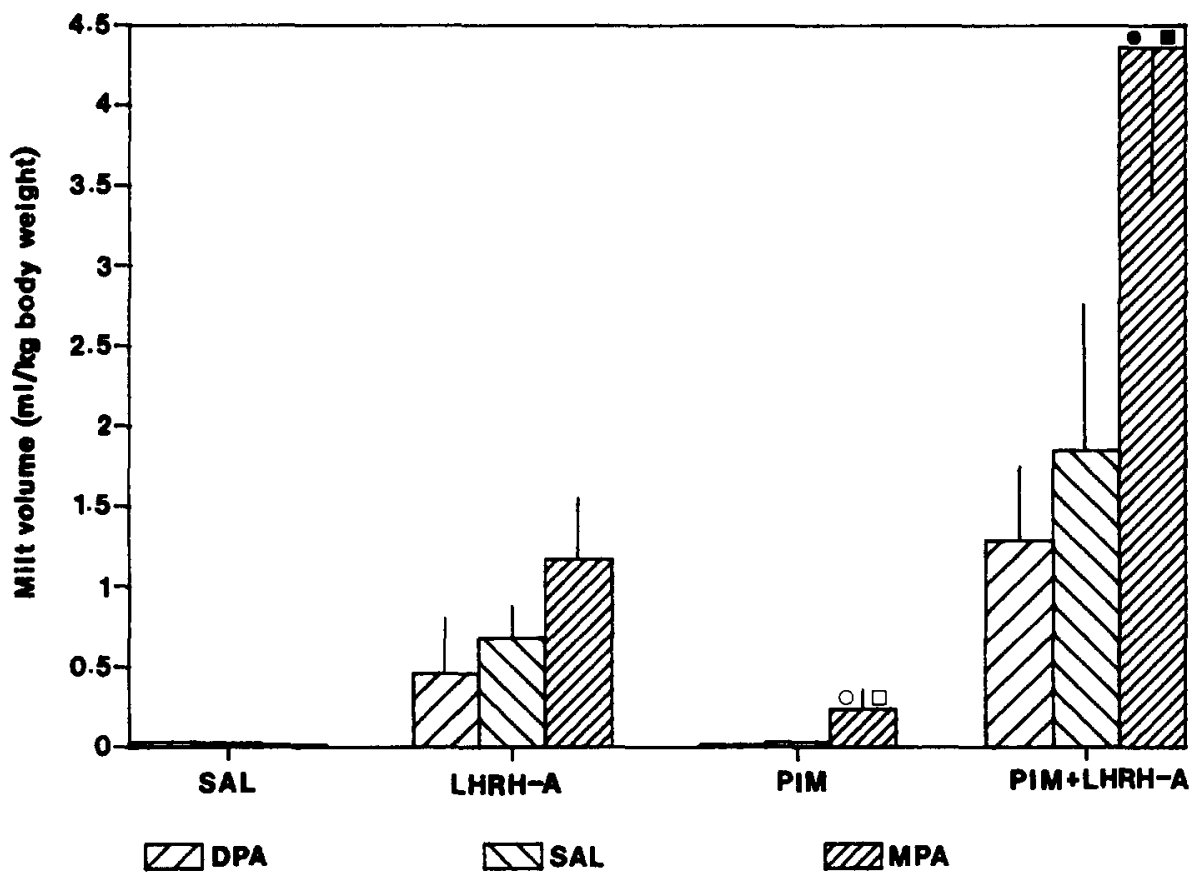

$\underline{\text { FIG. } 2}$

Spermiation response to the GABA-mimetic drug, DPA or to the inhibitor of GABA biosynthesis, MPA, alone or in combination with LHRH-a, PIM or LHRH-a + PIM, 24 hours after the second injection (treatment closure under 'Materials and Methods). Bars represent milt volume (mean $\pm \mathrm{SE}, \mathrm{N}=8$ ). $\mathrm{SE}$ not shown are too small for scale.

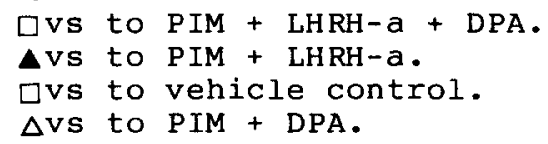

Before the injections, trace amounts of milt $(<0.3 \mathrm{ml})$ could be obtained. Twenty-four hours after the second injection the collectable milt volume from the males treated with the combination of MPA, PIM and LHRH-a was statistically higher than from the PIM + LHRH-a treated control group $(P<0.025)$ or from those carps that received DPA, PIM + LHRH-a $(P<0.025)$. The sperm production in the MPA, PIM + LHRH-a injected carps was significantly higher than in any other treatment group, also. In the vehicle control and in the LHRH-a treated group MPA or DPA did not alter significantly the volume of collectable milt.

When comparing to the vehicle injected control group, statistical analysis (U test) of the milt production results affirmed the stimulatory role of the combined administering LHRH-a and PIM $(P<0.005)$. The spermiating response to LHRH-a, however, did not differ statistically from the control group. Pimozide alone also did not alter milt production. On the other hand more sperm could be stripped from carps injected with MPA and PIM than from those that received DPA and PIM $(P<0.025)$. 
The distinct treatment group's milt production (ml/kg b.w.) correlated positive to the summarized posttreatment GtH values ( $P$ <0.01). The regression fitted to the theoretical equation $Y=$ $0.283-0.268 \mathrm{X}+0.067 \mathrm{X}^{2}(\mathrm{P}<0.005)(\mathrm{Y}=$ milt production, $\mathrm{X}=\mathrm{GtH}$, Fig 3).

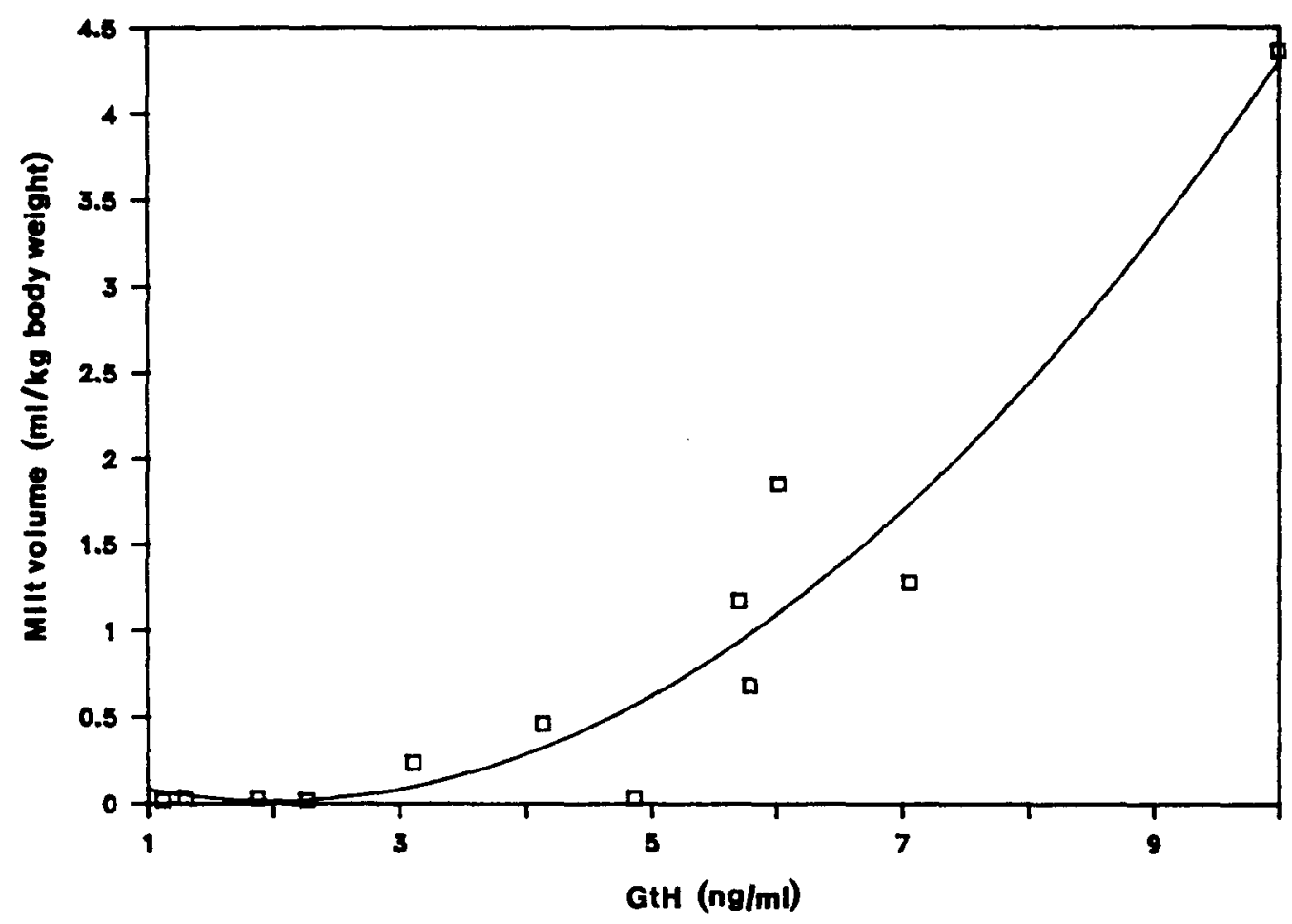

FIG. 3

Correlation between the milt production (ml/kg b.w.) in carp, assigned to different drug treatments, and the summarized GtH levels (ng/ml) of their serially collected plasma samples.

Experiment 2 .

Effects of MPA and GVG on PIM + LHRH-a stimulated GtH release in female carp.

a- Gonadotropin concentrations (Fig. 4). When compared to the vehicle control group (D), the secretion of pituitary GtH was stimulated by LHRH-a (B) $(\mathrm{P}<0.001)$ or by LHRH-a and PIM (A) (P 


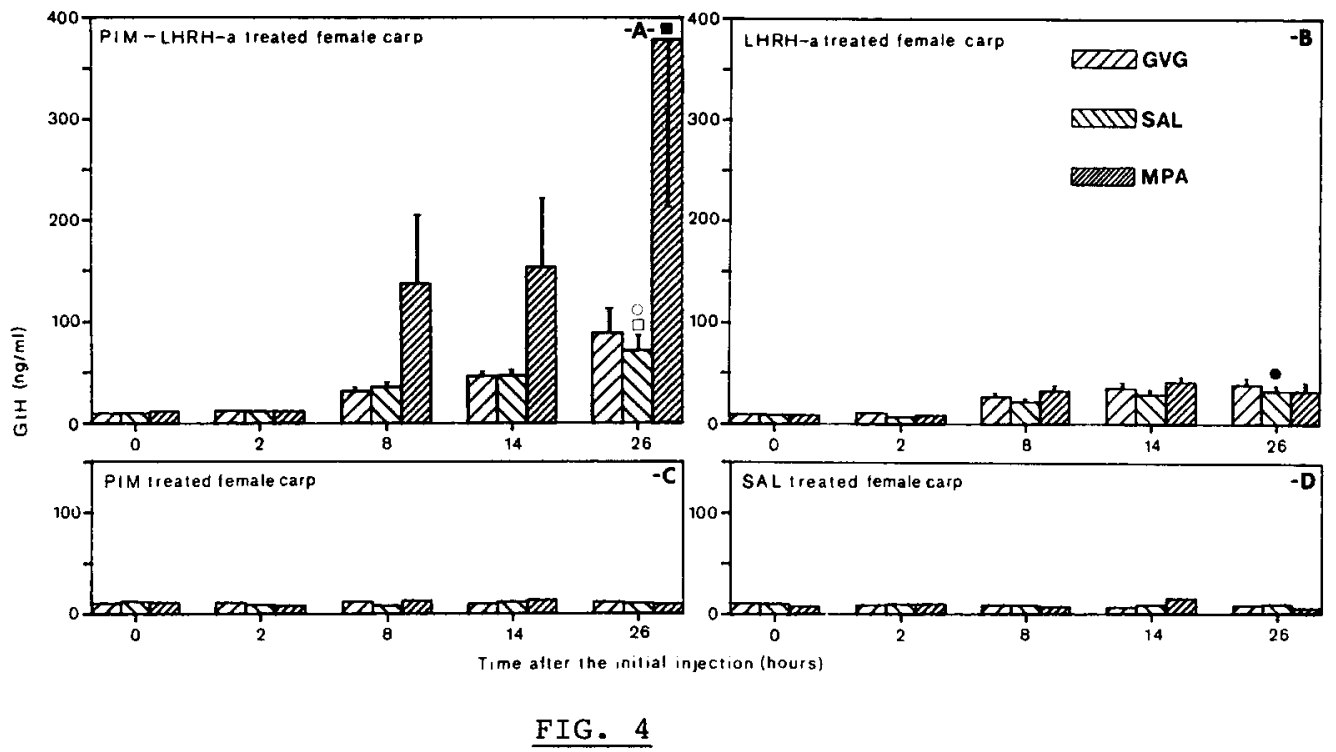

Effects of the irreversible inhibitor of GABA degradation, GVG and of the inhibitor of GABA biosynthesis, MPA, alone or in combination with LHRH-a, PIM or LHRH-a + PIM on the plasma GtH levels (mean $\pm \mathrm{SE}, \mathrm{N}=8$ ). $0 \mathrm{~h}$ and $2 \mathrm{~h}$ are the moment of the initial injection and of the second injection respectively (treatment closure under 'Materials and Methods). SE not shown are too small for scale.

Statistical differences in posttreatment $\mathrm{GtH}$ release :

ovs to vehicle control (in panel D).

- vs to vehicle control (in panel D).

-vs to PIM + LHRH-a (in panel A).

avs to LHRH-a (in panel B).

The increased GtH release response to the LHRH-a and PIM treatment (A) was also significantly higher than to LHRH-a alone (B) $(P<0.01)$. An additional injection of MPA enhanced the rise in plasma GtH concentrations induced by LHRH-a and PIM (A) (P < $0.05)$. But, in the control group and with the carps that received PIM (C) or LHRH-a (B) alone, the plasma GtH concentrations were unaffected by MPA. GVG did not alter spontaneous or stimulated GtH release.

b- Ovulating response. In the group treated with PIM + LHRH-a and additionally injected with MPA, DPA or the saline vehicle. ovulation was observed in respectively 4 of 7,2 of 7 and 3 of 7 females. These ovulation rates were not significant different (Fisher's exact test). Only one ovulation was observed in the group that received LHRH-a, while in the remaining groups none of the carps ovulated.

\section{Discussion}

The present data on female carp fit with the generally accepted model that, at least in cyprinid fish, blocking of the D2-dopamine receptors by pimozide potentiates the GtH release response to LHRH-a. 
In our experiments conducted on male carps the plasma GtH levels of the LHRH-a and of the PIM + LHRH-a treated groups were not significantly different. On the other hand, from the carps that received LHRH-a in combination with PIM (and not from those that received LHRH-a alone), 24 hour after the second injection, more milt could be stripped than from the saline treated controls.

Endocrinological data on GABA-ergic modulation of gonadotropin secretion from earlier experiments performed on mammals are somewhat puzzling. Part of the uncertainty in understanding is due to conflicting reports. While some investigators suggested that GABA stimulated the secretion of the luteinizing hormone ( $\mathrm{LH})(22,35)$, in contrast, others found an inhibitory role for GABA in the control of gonadotropin secretion $(26,36,37,38)$.

In our experiment conducted on female carp, the GtH release response to the LHRH-a + PIM treatment was clearly enhanced by administering the specific inhibitor of GABA synthesis, MPA. In male carps that were treated with PIM + LHRH-a the milt production induced by endogenous GtH was clearly higher than in any other treatment group, when MPA was injected additionally. But in male and female carps MPA did not affect spontaneous GtH release.

The results indicate an involvement of GABA in the dopaminergic and GnRH control of GtH release in carp. If GABA mediates the dopamine and GnRH action at the level of the pituitary gonadotrope cells directly, or indirectly by modulating the release of endogenous dopamine or endogenous $G n R H$ is not clear. MPA could diminish the inhibitory influence on GtH release by decreasing the synthesis or the release of dopamine at critical brain synapses. However, in males as well as in females, MPA did not alter the LHRH-a stimulated GtH release, indicating that this dopaminergic mechanism was not inhibited by a lower GABA-ergic tone. On the other hand, MPA could possibly stimulate the release of endogenous GnRH since a GABA-ergic inhibition of the release of LHRH is suggested for mammals $(23,37,38)$. In our experiment on female carp that received PIM to block the dopaminergic inhibition of GtH release, an additional injection of MPA did not change the plasma GtH values. Both these treatment groups had GtH values identical to the control values. This data indicate that in this case MPA did not evoke the release of endogenous GnRH. Between male carps injected with PIM and MPA and those that received PIM alone the posttreatment $\mathrm{GtH}$ release was also not statistically different. Similarly, data on the milt production in these males did not show a significant difference between the two groups. On the other hand, the posttreatment GtH values of the PIM and MPA injected males were slightly higher $(0.05>\mathrm{P}>0.04)$ than those in the saline injected controls. This is due to elevated GtH values at the moment of the second injection, 2 hours after the PIM and MPA administration. No such increase can be observed in the males that got PIM and MPA initially and LHRH-a two hours later.

While GVG, the irreversible inhibitor of GABA-T, did neither alter spontaneous nor stimulated GtH release in female carps. In males the GABA-mimetic drug, DPA, decreased significantly the increased $\mathrm{GtH}$ release response to LHRH-a. But DPA is not fully specific. It has been shown to lower the brain level of aspartaat (39). In rodents increased brain dopamine concentrations after DPA treatment have been reported $(40)$. It could be that in carp 
DPA lowers the increased GtH release response to LHRH-a by stimulating a mechanism other than the GABA-ergic.

Although in females MPA clearly enhanced the increased GtH release response to LHRH-a and PIM, the ovulation rates did not differ significantly between groups. But the experiment was performed almost a month (Mid-June) after the natural spawning season. A pretest was carried out earlier (Mid-May), using three groups of female carp $\left(2.05 \pm 0.24 \mathrm{~kg}, \mathrm{~b} . \mathrm{w}_{.}\right)$, originating from the same pond and subjected to an identical experimental procedure (treatment closure under "Materials and Methods"), but held at 20 ' $C$ without blood sampling. 32 hours after the second injection the ovulation rate ( 5 out of 10 ) in the group injected with MPA, PIM and LHRH-a was significantly higher than in the group treated with LHRH-a and PIM ( 0 out of 5 ) or with the saline vehicle ( 0 out of 5 ).

It was concluded that reduction of the endogenous GABA-ergic tone by administration of MPA does not alter spontaneous nor LHRHa stimulated GtH release, but clearly enhances the increased GtH release response to LHRH-a + PIM. GABA seems not to be involved directly in pituitary GtH release. It more likely modulates the action of endogenous dopamine and the gonadotropin releasing hormone. Further experiments concerning the role of the GABAergic mechanism in the neuroendocrine regulation of GtH release are currently under way.

\section{Acknowledgements}

We are indebted to Dr. G. Braem (Janssen Pharmaceuticals LtD.. Beerse. Belgium) for supplying the sample of Pimozide. We also are grateful to Dr. V. Mannes (Merell Dow, Belgium sa/nv) for providing GVG and to Dr. R. Buffels (Labaz-Sanofi, Brussels, Belgium) for the gift of DPA. The authors especially thank Mirka Sokolowska for critically reviewing the manuscript. The research was partially funded by Grant C.P.B.P. 05.06 from the Polish Government and by the Catholic University of Louvain. The visit by R. I. to Poland was supported by a Belgium - Poland Scientist Exchange Grant from the Flemish Ministry of Education.

\section{References}

1. R.E. PETER, J.P. CHANG, C.S. NAHORNIAK, R.J. OMELJANIUK, M. SOKOLOWSKA, S.M. SHIH and R. BILLARD, Recent Prog. Horm. Res. 42 513-548 (1986).

2. R.J. OMELJANIUK, H.R. HABIBI and R.E. PETER, proceedings of the Third International Symposium on the Reproductive Physiology of Fish. p. 35, Memorial University of Newfoundland (1987).

3. L.A.C. VAN ASSELT, H.J.Th. GOOS, W. SMET VAN DIJK, P. SPOETJENS and P.G.W.J. VAN OORDT, Proceedings of the Third International symposium on the Reproductive Physiology of Fish. p.43, Memorial University of Newfoundland (1987).

4. R. DE LEEUW, C. VAN 'T VEER, H.J.TH. GOOS and P.G.W.J. VAN OORDT, lst International Symposium on Fish Endocrinology. p13, University of Alberta (1988).

5. R. BILlard, K. AlagARSWAMI, R.E. PETER and B. BRETON, C.R. Acad. Sc. Paris. 296 181-184 (1983).

6. J.P. CHANG and R.E. PETER, Gen. Comp. Endocrinol. 52 30-37 (1983). 
7. M. SOKOLOWSKA, R.E. PETER, C.S. NAHORNIAK and J.P. CHANG, Can. J. Zool. 63 1252-1256 (1985).

8. M. SOKOLOWSKA, R.E. PETER, C.S. NAHORNIAK and J.P. CHANG, Gen. Comp. Endocrinol. $57472-479$ (1985).

9. R.E. PETER, C.S. NAHORNIAK, M. SOKOLOWSKA, J.P. CHANG, J.E. RIVIER, W.W. VALE, J.A. KING and R.P. MILLAR, Gen. Comp. Endocrinol. 58 231-242 (1985).

10. R. BILLARD, K. BIENIARZ, W. POPEK, P. EPLER, B. BRETON and K. ALAGARSWAMI, Aquaculture. 62 161-170 (1987).

11. R. BILLARD, P. REINAUD, M.G. HOLLEBECQ and B. BRETON, Aquaculture. $4347-66$ (1984).

12. R. DE LEEUW, J.W. RESINK, E.J.M. ROOYAKKERS and H.J.TH. GOOS, Gen. Comp. Endocrinol. 58 120-127 (1985).

13. H.R. LIN, G. VAN DER KRAAK, R.E. PETER and B. BRETON, Gen. Comp. Endocrinol. 64 389-395 (1986).

14. H.R. LIN, X.J. ZHOU, G. VAN DER KRAAK and R.E. PETER, Proceedings of the Third International Symposium on the Reproductive Physiology of Fish. p33, Memorial University of Newfoundland (1987).

15. J.P. CHANG, A.F. COOK and R.E. PETER, Gen. Comp. Endocrinol. $4922-31$ (1983).

16. J.P. CHANG, D.S. MACKENZIE, D.R. GOULD and R.E. PETER, Life SCI. 35 2027-2033(1984).

17. J.P. CHANG and R.E. PETER, Gen. Comp. Endocrinol. 55 89-95 (1984).

18. P.M. ROSENBLUM and R.E. PETER, Proceedings of the Third International symposium on the Reproductive Physiology of Fish. p37, Memorial University of Newfoundland (1987).

19. G. SOMOZA, K.L. YU and R.E. PETER, Proceedings of the Third International symposium on the Reproductive Physiology of Fish. p39, Memorial University of Newfoundland $(1987)$.

20. B. BRETON, J.M. DANGER, T. MIKOLAJCZYK, F. GONNET and M. VAUDRY, 1st International Symposium on Fish Endocrinology. p21, University of Alberta Edmonton (1988).

21. O. KAH, A. PONTET, J.M. DANGER, P. DUBOURG, G. PELLETIER, M. VAUDRY and A. CALAS, 1st International Symposium on Fish Endocrinology. p21, University of Alberta Edmonton (1988).

22. E. VIJAYAN and S.M. MCCANN, Brain Research $15535-43$ (1978).

23. C. LERANTH, N.J. MACLUSKY, H. SAKAMOTO, M. SHANOBROUGH and F. NAFTOLIN, Neuroendocrinology 40 536-539 (1985).

24. T. MANSKY, P. MESTRES-VENTURA and W. WUTTKE, Brain research $231353-364$ (1982).

25. K. FUXE, K. ANDERSON, S.O. OGREN, M. PEREZ DE LA MORA, R. SCHWAREZ, T. HOKFELT, P. ENEROTH, J-A GUSTAFSSON and P. SKETT, GABA-Neurotransmitters. p74-94, Munksgaard, Copenhagen (1979).

26. R. LAMBERTS, E. VIJAYAN, M. GRAF, T. MANSKY and W. WUTTKE, Exp. Brain Res. 52 356-362 (1983).

27. D.W. GALLAGER and G.K. AGHAJANIAN, Europ. J. Pharm. 39357 -364 (1976).

28. W. LASON, B. PRZEWLOCKA and R. PRZEWLOCKI, Life SCi. 33 Suppl. 1 599-602.

29. O. KAH, P. DUBOURG, M.G. MARTINOLI, M. GELFARD and A. CALAS, Experientia 43 no3 300-301 (1987). 
30. M.E. FOlleniUs, C.R. Acad. Sci. Paris, 275 Serie D 1435

$-1438(1972)$.

31. W. LOSCHER, Biochem. Pharmacol. 28 1397-1407 (1979).

32. Y. GODIN, L. HEINER, J. MARK and P. MANDEL, J. Neurochem. 16 869-873 (1969).

33. W. LOSCHER and H. FREY, Europ. J. Pharmacol. 143 335-342 (1987).

34. B. BRETON, G. KANN, E. BURZAWA-GERARD and R. BILLARD, C.R. Acad. Sci. 272 1515-1517 (1971).

35. J.G. ONDO, Science $186738-739$ (1974).

36. A.N. ELIAS, A.V. SZEHERES, S. STONES, L.J. VALENTA, T. HAW and M.S. ASCHER, Acta Endocrinologia 103 451-456 $(1983)$.

37. A.A. BENJAMIN and R.C. WILLIAM, Endocrinology $11891-97$ (1986)

38. C. MASOTTO and A. NEGRO-VILAR, Endocrinology 121 2251-2255 $(1987)$.

39. D.R. BURT and R.L. TAYLOR, Endocrinology 106 1416-1423 (1980)

40. K. KUKINO and T. DEGUCHI, Chem. Pharm. Bull. 25 2257-2262 $(1977)$. 